\title{
Nuclear Criticality Safety Assessment for Tank 38H Salt Dissolution
}

by

R. H. Ross

Westinghouse Savannah River Company

Savannah River Site

Aiken, South Carolina 29808

Dimisution of MAS DOCUMENT is UNLMTTEO

DOE Contract No. DE-AC09-89SR18035

This paper was prepared in connection with work done under the above contract number with the U.S. Department of Energy. By acceptance of this paper, the publisher and/or recipient acknowledges the U.S. Government's right to retain a nonexclusive, royalty-free license in and to any copyright covering this paper, along with the right to reproduce and to authorize others to reproduce all or part of the copyrighted paper. 


\section{DISCLAIMER}

This report was prepared as an account of work sponsored by an agency of the United States Government. Neither the United States Government nor any agency thereof, nor any of their employees, makes any warranty, express or implied, or assumes any legal liability or responsibility for the accuracy, completeness, or usefulness of any information, apparatus, product, or process disclosed, or represents that its use would not infringe privately owned rights. Reference herein to any specific commercial product, process, or service by trade name, trademark, manufacturer, or otherwise does not necessarily constitute or imply its endorsement, recommendation, or favoring by the United States Government or any agency thereof. The views and opinions of authors expressed herein do not necessarily state or reflect those of the United States Government or any agency thereof.

This report has been reproduced directly from the best available copy.

Available to DOE and DOE contractors from the Office of Scientific and Technical Information, P.O. Box 62, Oak Ridge, TN 37831; prices available from (615) 576-8401.

Available to the public from the National Technical Information Service, U.S. Department of Commerce, 5285 Port Royal Road, Springfield, VA 22161. 


\section{DISCLAIMER}

Portions of this document may be illegible electronic image products. Images are produced from the best available original document. 
HIGH LEVEL WASTE ENGINEERING

HLW ENGINEERING SUPPORT

NUCLEAR CRITICALITY SAFETY ASSESSMENT FOR TANK 38H SALT DISSOLUTION (U)

December 23, 1996

R. H. Ross

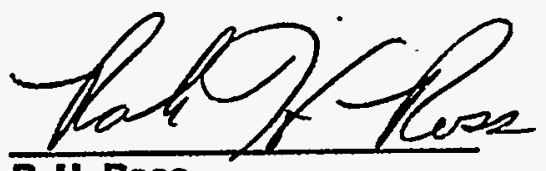

R.H. Ross

Author

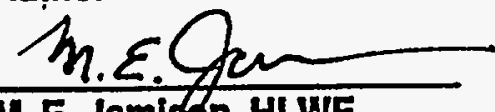

M. E. Jamisoon, HLWE

Technical Reviewer

Milenl. Qho

M.C. Chandler, Manager ore

HLWE Characjerization

$B 212$

B. L Lewis, Manager

HLWE Support

Q1 Le for U.G.D:ikert

T. M. Monahon, Manager

High Level Waste Engineering
WSRC-TR-96-0336

REVISION: 1

KEYWORDS:

High Level Waste

Saltcake

Tank 38H

Criticality

Retention:

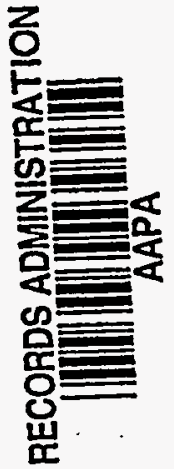

10 Years

CLASSIFICATION:

UNCLASSIFIED

Does not contain UCNI

R.R. Whstew $12 / 30 / 96$ Cuthorizod

Derivative Classifier

Date: $12 / 19 / 96$

Date: $12 / 23 / 96$

Date: $12 / 22 / 96$

Date: $12 / 23 / 96$

Date: $1 / 2,3196$ 


\section{Revision History}

Rev. 0, $10 / 96$

Initial issue

Rev. 1, $12 / 96$ November Decant. Incorporated additional sample results from October and November 1996. Additionally, insignificant salt dissolution was observed from video inspection and no samples would be required until the evaporator concentrate is less saturated in salts (i.e., salt dissolution would occur).

Additional text changes have been made to change this report from a initial assessment to an ongoing assessment. 
TABLE OF CONTENTS

REVISION HISTORY

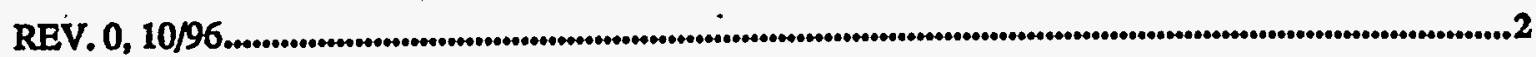

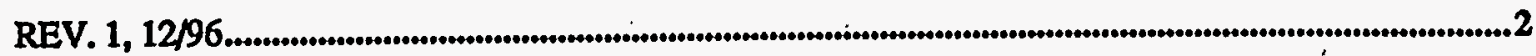

1. SUMTMARY

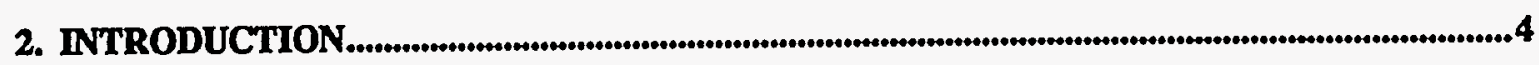

3. DISCUSSION

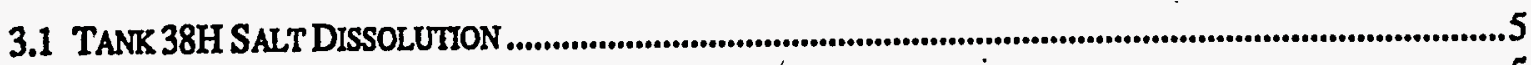

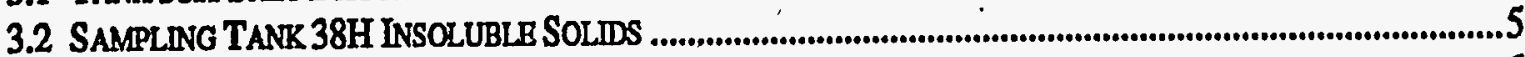

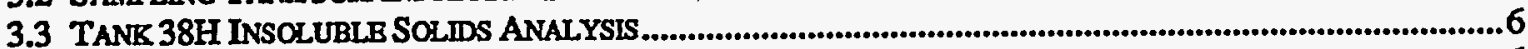

3.4 TANK 38H INSOLUBLB SOLIDS ANALYSIS RESULTS...........................................................................6

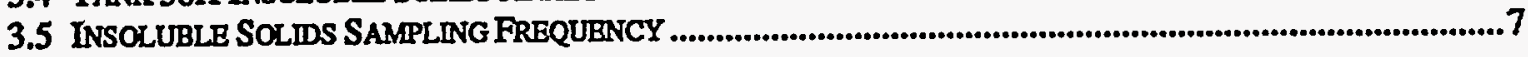

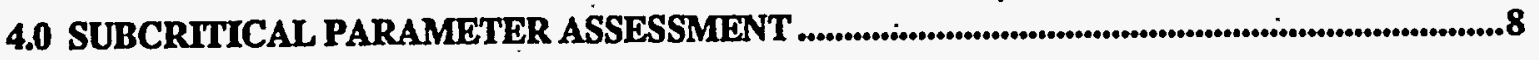

4.1 SINGLE ELEMENT NEUTRON POISON RATIOS ........................................................................................8

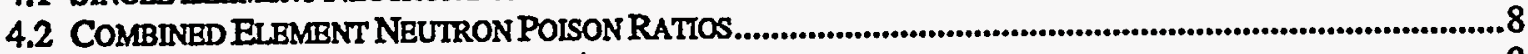

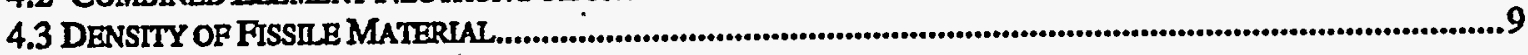

5.0 CRITERIA FOR FUTURE SALT DISSOLUTION IN TANK 38H ...............................................9

\section{INDEX OF TABLES}

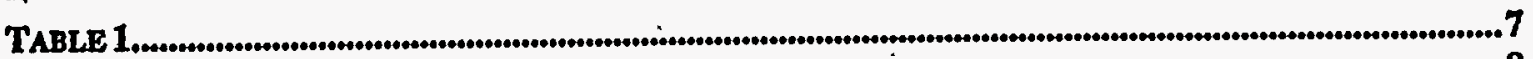

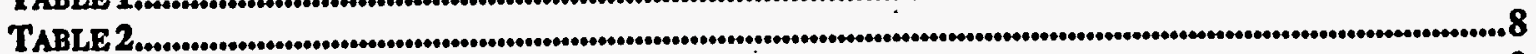

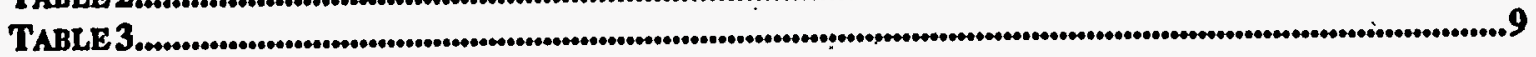




\section{Summary}

The accumulating insoluble solids sample results from Tank $38 \mathrm{H}$ demonstrates that an inherent subcritical condition for nuclear criticality safety exists during saltcake dissolution. This report also defines criteria for future sampling of Tank $38 \mathrm{H}$ for continued verification of the inherent subcritical condition as saltcake dissolution proceeds. Current Tank 38H sample results demonstrate subcritical conditions based on neutron poisons to fissile ratios. These ratios are summarized below, ${ }^{12,34}$

Visual inspection of the salt surface on November 6, 1996 revealed that insignificant salt dissolution had occurred in Tank 38H during the most recent fill cycle. The lack of salt dissolution is principally due to the chemistry of the $242-16 \mathrm{H}$ evaporator system. The evaporator system has become saturated in nitrate salts, thus the evaporator concentrate solution cannot dissolve the existing saltcake. The saturated conditions will continue until the concentrated liquor is transferred out of the evaporator system (i.e., parked). Therefore, no additional sampling will be required until the evaporator feed becomes unsaturated in salt forming compounds (e.g., removing concentrate liquor from the $242-16 \mathrm{H}$ evaporator system). Saltcake monitoring shall be accomplished via salt soundings at two different locations of the tank and panoramic video inspection of the salt surface.

\section{Tank 38H Neutron Poison Ratios}

\begin{tabular}{|c|c|c|c|c|}
\hline Sample No. & Na & Cr & Fe & Mn \\
\hline Safe Ratio & 150 & 66 & 76 & 30 \\
\hline HTF-003 & 3,700 & 310 & 630 & 1,100 \\
\hline HTF-004 & 16,000 & 40 & 98 & 34 \\
\hline HTF-005 & 40,000 & 93 & 62 & 23 \\
\hline
\end{tabular}

\section{Introduction}

Distributed throughout the saltcake are insoluble solids containing fissile material. As the saltcake dissolves the insoluble solids can accumulate. Thus, dissolution of saltcake requires verification of subcritical conditions. The goal of the criticality safety program in HLW is to demonstrate an inherent subcritical condition exists to allow bulk saltcake dissolution to occur without the need to implement criticality safety controls. It is a requirement to demonstrate that the accumulating insoluble solids containing fissile material are inherently subcritical for all process conditions or implement criticality safety controls to prevent a criticality. ${ }^{3}$

Dissolution of saltcake occurs whenever saltcake is contacted by solution that is unsaturated in salts. Nitrite and nitrate compounds are the main saltcake constituents; therefore, if the solution contacting the saltcake is unsaturated in these salts, salt dissolution occurs. Salt dissolution from small volume additions (e.g., rain water additions, etc.) have considerable less potential than bulk salt dissolution to result in the accumulation of insoluble solids that were distributed throughout the saltcake. ${ }^{6}$

Bulk saltcake dissolution may occur due to the large volume of unsaturated salt solution such as Defense Waste Processing Facility (DWPF) recycle waste being fed into the $242-16 \mathrm{H}$ evaporator system. This system includes Tank 38H that is the focus of this assessment. Salt dissolution has intentionally been performed in Tank $41 \mathrm{H}$, previously the $242-16 \mathrm{H}$ concentrate receipt tank, by a waste removal project. 
Data from insoluble material obtained during the initial Tank $41 \mathrm{H}$ salt dissolution has supported the inherent subcritical parameters for Tank 38H dissolution.'

Saltcake that has been formed as a result of operating the $242-16 H$ evaporator is a concern for criticality safety for a number of reasons: 1) high enriched uranium and plutonium discards were received in the HArea tank farm, 2) during evaporation the soluble uranium in solution can reach saturation conditions and crystallize from solution, and 3) large volume reductions of solution occurred in this evaporator system increasing the potential for uranium to have exceeded saturation. Plutonium is also present as fissile material and is accounted for as equivalent uranium.

It is also recognized that the insoluble material found in saltcake will be inherently subcritical for the following reasons: 1) uranium is not the only element that crystallizes from evaporate concentrate solution as an insoluble solid, 2) sludge solids are expected due to the fact sludge settling is not a requirement of the 242-16H evaporator system, and 3) most insoluble solids are neutron poisons or diluents.

This assessment report is provided to demonstrate the inherent criticality safety of Tank 38H solids that will accumulate during saltcake dissolution. The sample results continue to confirm that sufficient neutron poisons are associated with the fissile material contained in insoluble solids which accumulate during saltcake dissolution. This report also provides guidance for verification of subcritical conditions for continued dissolution of saltcake in Tank $38 \mathrm{H}$.

\section{Discussion}

\subsection{Tank 38H Salt Dissolution}

Since the receipt of DWPF.recycle, a very dilute salt solution, the feed to the $242-16 \mathrm{H}$ evaporator system has been lower in salt content. Therefore, the evaporator concentrate can be unsaturated and has the capacity to dissolve salt.

Initial saltcake dissolution in Tank 38H occurred when unsaturated solution contacted the saltcake that had formed on the cooling coils. Further saltcake dissolution will be hindered by the saturated salt solution above the saltcake. This is due to the fact that typical saturated salt solution has a higher specific gravity than the unsaturated salt solution. Photographs taken after decanting the concentrate from Tank 38H demonstrate the changing conditions of the saltcake (Revision 0 ).

In Tank 38H, salt dissolution is limited by a number of factors: 1) salt dissolution occurs only if the unsaturated solution contacts the saltcake, 2) salts dissolution kinetics, and 3) required heat of salt dissolution (i.e., endothermic reaction).

\subsection{Sampling Tank 38H Insoluble Solids}

Sampling of insoluble solids in Tank $38 \mathrm{H}$ has been accomplished by use of a variable depth sampler (VDS) and a saitcake coring device. The variable depth sampler has an aluminum foil covering over the sample bottle mouth that dissolves away in the alkaline tank environment. To obtain a sample of the accumulating insoluble solids using the variable depth sampler, the sampler must be lowered to the desired elevation prior to the foil dissolving. The saltcake core sampler is a hollow tube designed to retain the saltcake when extracted.

The following is a discussion of each individual sample obtained from Tank $38 \mathrm{H}$. Four samples have been obtained to date and the results are listed in this report. Three of the samples are VDS samples (HTF-001, HTF-004 \& HTF-005) that represent in-situ conditions of solids accumulating above the saltcake. The third sample is a salt core sample (HTF-003) that predicts the expected components of 
future saltcake dissolution including the solids accumulating above the saltcake. Current results indicate more than ample neutron poisons are present to maintain subcriticality. 8,9

\section{Tank 38H VDS Sample HTF-001}

Date: October 4, 1996 Riser: H Depth: 6" above saltcake

After washing the insoluble solids with inhibited water, the washed sample quantity was too small for complete analysis. The insufficient sample volume is attributed to the 772-F Laboratory sample preparation of this first sample. No results will be forthcoming from this sample.

Tank 38H Salt Core Sample HTF-003

Date: October 10, 1996

Riser: H Depth: Salt/Supernate Interface

The sampler was driven into the saltcake approximately 12 inches to obtain a sample of saltcake for analysis. ${ }^{3,8}$ This sample has been repeatedly washed with inhibited water to remove soluble constituents.

\section{Tank 38H VDS Sample HTF-004}

Date: October 10, 1996

Riser: H Depth: Salt/Supernate Interface

Sample results indicate that a massive amount of neutron poisons are available at the salt surface. Sample results are reported in Tables 1,2 , and 3. This sample represents the bulk solids accumulating in the tank.

Tank 38H VDS Sample HTF-005

Date: November 21, 1996

Riser: H Depth: Salt/Supernate Interface

Sample results indicate that a massive amount of neutron poisons are available at the salt surface. Sample results are reported in Tables 1,2 , and 3. This sample represents the bulk solids accumulating in the tank.

\subsection{Tank 38H Insoluble Solids Analysis}

The analysis of Tank 38H insoluble solids is performed by the Savannah River Technology Center (SRTC). The samples are highly radioactive and are delivered to the SRTC Shielded Cells in shielded doorstops. Within the Shielded Cells facility the samples are prepared for analysis. Preparation is required to: 1) prepare a subsample of the total "as received" sample, 2) wash soluble solids from the insoluble solids, and 3) prepare a subsample of the insoluble solids for analysis.

Additional details of the SRTC sample preparation and analysis effort are defined in a Test Plan? requested by a HLWE Technical Task Request. ${ }^{10}$ 


\subsection{Tank 38H Insoluble Solids Analysis Results}

Table 1 below lists the sample analysis results for the insoluble solids that will be used to demonstrate subcritical conditions exist in Tank 38H. Additional results and details may be found in the SRTC Technical Report describing the sample analyses and results ${ }^{1,8}$.

Table 1

Tank 38H Insoluble Solids Sample Results (wt.\%)

\begin{tabular}{|c|c|c|c|c|c|}
\hline Sample No. & $\mathrm{Na}$ & $\mathbf{C r}$ & $\mathrm{Fe}$ & $\mathbf{M n}$ & $\mathbf{U}_{\mathrm{ce}}^{235}$ \\
\hline HTF-003 & 17 & 1.4 & 2.9 & 5.0 & 0.0045 \\
\hline HTF-004 & 27 & 0.067 & 0.16 & 0.057 & 0.0017 \\
\hline HTF-005 & 30 & 0.072 & 0.048 & 0.018 & 0.00077 \\
\hline
\end{tabular}

\subsection{Insoluble Solids Sampling Frequency}

This section describes the initial salt dissolution conditions in Tank $38 \mathrm{H}$ as initially encountered in October 1996. Sampling criteria beyond these initial conditions are defined in Section 5.0.

Salt sample(s) (e.g., VDS, salt core sampler) will be taken prior to the next decant from Tank $38 \mathrm{H}$ to confirm that adequate neutron poisons are present. Minimal salt dissolution is expected from the addition of supernate to Tank 38H because of the layering effect. The duration between Tank 38H decants is expected to be between 1 to 2 months depending on the variable evaporator concentrate drop rate and the scheduled direct receipt of DWPF recycle into Tank $38 \mathrm{H}$

Minimal salt dissolution is expected in Tank 38H with the present fixed jet configuration (i.e., 248 inches) and the supernate stratified layering behavior. All additions to Tank $38 \mathrm{H}$ are made through inlets at or above the operating fill limit of 362 inches. Depending on the specific gravity of the solutions and the current Tank $38 \mathrm{H}$ supernate specific gravity profile, supernate (or concentrate) additions will stratify and form a layer in the tank with respect to their specific gravity. The layering occurs because Tank $38 \mathrm{H}$ has no mechanical mixing. The only solution mixing that occurs within the tank is from diffusion, thermal gradients (e.g., hot concentrate), and the agitation from supernate addition and extraction.

Therefore, the supernate behavior can be described in Tank $38 \mathrm{H}$ based on the influent supernate characteristics. This behavior has been observed during the gradient density testing at SRTC."

(1) when supernate additions have a low specific gravity and supernate is covering the saltcake, the saltcake will not be contacted by the low specific gravity supernate. Therefore, if the supernate addition is unsaturated, saltcake dissolution is expected to occur by two mechanisms: diffusion (slow) and thermal mixing.

(2) when supernate additions have a high specific gravity, the saltcake will be contacted by displacing lower specific gravity supernate. If the supernate addition is unsaturated, salt dissolution will occur.

(3) supernate additions will cause localized salt mining due to the contact with the salt layer if the supernate is unsaturated. This effect is significantly mitigated as the supernate level increases since the supernate layer prevents contact with the salt layer. 
Additionally, salt dissolution will be impeded due to the current Tank $38 \mathrm{H}$ jet suction elevation (248 inches) and the maximum salt cake elevation ( -254 inches) from video inspection. Initially after each decant, the saltcake will be exposed to the influent supernate additions. Salt dissolution will occur if the supernate is unsaturated. Unsaturated supernate will become saturated which will cause an increase in specific gravity. As additional supernate is added, it will follow the supernate behavior described above.

Eventually Tank $38 \mathrm{H}$ salt elevation will approach 248 inches and a saturated supernate layer is expected to remain over the salt cake after each decant. Salt dissolution below 248 inches is expected at a slow rate since the salt dissolution will be occurring from diffusion and thermal mixing. As mentioned previously, localized salt dissolution will occur below the drop point, so some salt dissolution may occur below the 248 inch elevation.

\subsection{Subcritical Parameter Assessment}

\subsection{Single Element Neutron Polson Ratios}

Listed below in Table 2 are the weight ratios of single element neutron poisons to fissile material identified in the insoluble material that accumulates in Tank $38 \mathrm{H}$. The safe weight ratios ${ }^{1}$ were established in the referenced Nuclear Criticality Safety Evaluations (NCSEs). ${ }^{2,3,4}$ The nuclear criticality "safe ratio" is the amount of inherent neutron poisons to uranium that will maintain a mixture subcritical under all conditions; therefore, all weight ratios greater than the safe ratio are considered subcritical and safe.

Table 2

1 Tank 38H Single Element Weight Ratios to Fissile Material

\begin{tabular}{|c|c|c|c|c|}
\hline Sample No. & Na:U & Cr:U $_{\mathrm{se}}$ & Fe:U $_{s e}$ & Mn:U $_{\mathrm{sq}}$ \\
\hline Safe Ratio & 150 & 66 & 76 & 30 \\
\hline HTF-003 & $3700: 1$ & $310: 1$ & $630: 1$ & $1100: 1$ \\
\hline HTF-004 & $16,000: 1$ & $40: 1$ & $98: 1$ & $34: 1$ \\
\hline HTF-005 & $40,000: 1$ & $93: 1$ & $62: 1$ & $23: 1$ \\
\hline
\end{tabular}

\subsection{Comblned Element Neutron Poison Ratios}

Listed in Table 3 is the weight ratio of combined neutron poisons to fissile material identified in the insoluble material accumulating in Tank 38H. The safe weight ratio was established in the referenced Nuclear Criticality Safety Evaluation (NCSE)." The nuclear criticality "combined safe ratio" is the ratio of inherent neutron poisons to each other as compared to uranium. The combined ratio will maintain a mixture subcritical under all conditions; therefore, all weight ratios greater than the combined safe ratio are considered subcritical and safe. 


\section{Table 3}

Tank 38H Combined Element Weight Ratio to Fissile Material

\begin{tabular}{|c|c|}
\hline Sample No. & Fe:Mn:U \\
\hline Safe Ratio & $20: 20: 1$ \\
\hline HTF-003 & $630: 1100: 1$ \\
\hline HTF-004 & $98: 34: 1$ \\
\hline HTF-005 & $62: 23: 1$ \\
\hline
\end{tabular}

\subsection{Density of Fissile Material}

The maximum fissile material density is the weight percent fissile material of the insoluble solids times the maximum settled insoluble solids density. If the maximum settled solids density is not determined, then it is conservative to use the maximum crystalline density of the insoluble solids. Even the average crystalline density of the insoluble solids represents a conservative assumption. This is a conservative assumption for conditions in HLW because to achieve the crystalline densities, the insoluble solids would need to be dewatered and lattice voids filled.

The effective density of the initial salt dissolution cycle for Tank $38 \mathrm{H}$ is calculated by multiplying the total fissile material weight percent by the uranium density $\left(3.93 \mathrm{~g} / \mathrm{cc}\right.$ ) of uranium precipitate solids. ${ }^{12}$ Thus, if the Tank 38H insoluble solids on the salt surface have an average density of $3.93 \mathrm{~g} / \mathrm{cc}$, then the uranium concentration could be derived by applying the effective weight percent of the uranium solids to the precipitated solids layer.

$$
\mathrm{U}_{\mathrm{eq}} \text { Density }^{\mathrm{Th} 3 \mathrm{~kg}}=0.0045 \mathrm{wt} \% \mathrm{U}_{\mathrm{eq}} \cdot \frac{1 \mathrm{wt} \text { fraction }}{100 \mathrm{wt} \%} \cdot \frac{3.93 \mathrm{~g}}{\propto c} \cdot \frac{1,000 c \mathrm{c}}{\text { liter }}=0.18 \frac{\mathrm{g}}{\mathrm{L}} \mathrm{U}_{\mathrm{eq}}
$$

Thus it is shown that the density of Tank $38 \mathrm{H}$ precipitated solids (i.e., slurry) is below the aqueous solution ANSL/ANS 8.1 single parameter limit of $11.6 \mathrm{~g} / \mathrm{L}$. The factor of safety is the ratio of $11.6 / 0.18 \mathrm{or}$ 64. This implies not only would the uranium bearing solids be required to settle to $3.93 \mathrm{~g} / \mathrm{cc}$, but the slurry would force the lattice void spaces to be filled 64 times yielding an incredible mixture density of $251 \mathrm{~g} / \mathrm{cc}$. This fissile mass density calculation is given strictly for comparison to the safety factor for a hydrogen-poisoned liquid system. Tank 38H is heavily poisoned by inherent neutron absorbers common to the saltcake formation process; therefore, the aqueous solution concentration of $11.6 \mathrm{~g} / \mathrm{L}$ is conservative because of the inherent elemental (e.g., nitrogen) replacement of the aqueous hydrogen component. The subcritical reactivity of the tank under all scenarios is demonstrated by the neutron poison to fissile material weight ratios. ${ }^{3}$ 


\subsection{Criteria for Future Salt Dissolution in Tank 38H}

This section contains a discussion of expected conditions in Tank $38 \mathrm{H}$ and criteria for future sampling. The HLWE Criticality Safety Engineer is responsible for monitoring Tank 38H conditions. The HLW Criticality Safety Engineer has "Stop Work" authority if the technical basis cannot be verified.

\section{November 1996 Sampling Criteria}

This decant transfer has been evaluated and determined to be within the safety basis by the data in Table 1 and the video comparison inspection performed November 6,1996 . The November video comparison establishes the layering and saturated solution postulates of Section 3.1. Another VDS salt sample (HTF005) was obtained from the salt surface on November 21, 1996 in order to expand the salt sample database.

\section{January 1997 Sampling Criteria}

At this time, saltcake dissolution in Tank $38 \mathrm{H}$ is expected to be limited due to the saturated state of the Tank $38 \mathrm{H}$ supernate $(\sim 6.86 \text { molar } \mathrm{OH})^{5}$. The saturated conditions will continue until the concentrated liquor is transferred out of the evaporator system (i.e., parked). Otherwise, the supernate will continue to be saturated due the recycle transfers and evaporation cycles. Additionally, salt deposition may occur in Tank 38H due to the saturation of evaporator feed. Therefore, no additional sampling will be required until the evaporator feed becomes unsaturated in salt forming compounds (e.g., removing concentrate liquor from the $242-16 \mathrm{H}$ evaporator system). Saltcake monitoring shall be accomplished via salt soundings at two different locations (i.e., $\mathrm{G}$ and $\mathrm{H}$ risers) of the tank and panoramic video inspection of the salt surface.

\section{Future Sampling Criteria}

The next assessment point will be after the concentrated liquor is transferred from the $242-16 \mathrm{H}$ evaporator system. At this assessment the HLWE Criticality Safety Engineer will determine specific actions. Active sampling will not be necessary again until the concentrated liquor is transferred out of the $242-16 \mathrm{H}$ evaporator system (i.e., parked). This report will not be revised again until the concentrated liquor is removed from the evaporator system (i.e., salt dissolution is again possible). 
1 WSRC-RP-96-0544, "Preliminary Analytical Results for Tank Farm Samples in Support of Salt Dissolution Evaluations (U)," D. T. Hobbs, Rev. 0, 10/21/96.

2 EPD-CTG-960046, "Metal Poisons in Waste Tanks," T.G. Williamson, 7/31/96.

${ }^{3}$ N-NCS-H-00034, Nuclear Criticality Safety Evaluation - "Minimum Safe Ratios of Inherent Saltcake Metals to Uranium," R.H. Ross, 10/14/96.

4 WER-WME-92-1143, Nuclear Criticality Safety Analysis WM-92-3 "Minimum Safe Ratios of Fe and Mn to U-235 in an Infinite System (U)," J. S. Clemmons, 9/18/92.

5 HLW-HLE-96-0363, "Tank Chemistry Report, October 1996", L.S. Livingston, 11/22/96

6 WSRC-TR-93-0081, "Evaluation of Potential Accumulation of Uranium and/or Plutonium in the HLW Evaporator Systems (U)," M. C. Chandler, Rev. 0, 2/1/93.

7 WSRC-TR-94-0057, "Final Report: Analysis of Tank 41H Saltcake Samples \#2 and Comparison to Sample \#1," D.T. Hobbs, 1/26/94.

"WSRC-RP-96-0623, “Analytical Results for Tank 38H Sample HTF-005," D. T. Hobbs, Rev. 0, $12 / 19 / 96$.

9 WSRC-RP-96-0526, "Technical Task Plan for the Analysis of Tank Farm Samples in Support of Salt Dissolution Evaluations (U)," D. T. Hobbs, Rev. 0, 10/13/96.

${ }^{10}$ HLE-TTR-97-003, “Tank 38 Salt Analysis to Determine Neutron Poisons," 10/9/96.

${ }^{11}$ WSRC-TR-96-0160, "An Investigation of Density Driven Salt Dissolution Techniques (U)," B. J. Weirsma, Rev. $0,8 / 96$.

12 WSRC-RP-94-1213, "Characterization of the Tank 41H Saltcake Insoluble Solids," D. T. Hobbs, 10/31/94.

Distribution:

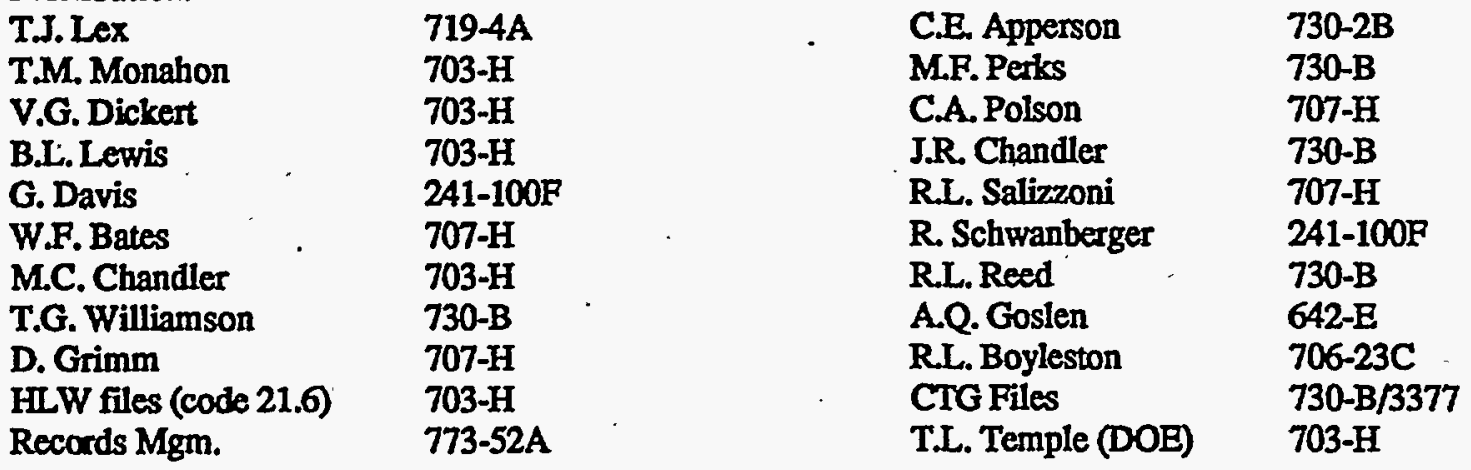

